\title{
Turf Performance of Shaded 'TifGrand' and 'TifSport' Hybrid Bermudagrass as Affected by Mowing Height and Trinexapac-ethyl
}

\author{
Brian Schwartz ${ }^{1}$, Jing Zhang ${ }^{1}$, Jonathon Fox ${ }^{1}$, and Jason Peake ${ }^{2}$
}

ADDITIONAL INDEX WORDs. plant growth regulator, reduced light intensity, turfgrass breeding

SUMMARY. Heavily shaded environments often limit the performance and persistence of hybrid bermudagrass (Cynodon dactylon $\times$ C. transvaalensis), therefore a fieldbased shade study was performed to determine whether different mowing heights (0.5 and 1.5 inch) or two trinexapac-ethyl (TE) growth regulator management treatments (control and $2 \mathrm{oz} / \mathrm{acre}$ ) allow either 'TifSport' or 'TifGrand' hybrid bermudagrass to persist under $77 \%$ shade. Turfgrass quality (TQ), green cover, normalized difference vegetation index (NDVI), and dark-green color index (DGCI) were evaluated on the two cultivars under a shade structure in Tifton, GA, during 2010 and 2011. Neither of the cultivars maintained acceptable TQ throughout the entire year under $77 \%$ shade, although 'TifGrand' displayed adequate TQ at the higher mowing height $(1.5 \mathrm{inch})$ and demonstrated more shade tolerance than 'TifSport', as indicated by TQ, green cover, and NDVI. The TE application did not enhance the turf performance of 'TifSport' under $77 \%$ shade when mowed at 0.5 inch, but it improved turf performance of 'TifGrand' at the same height. The effect of TE application was cultivar and mowing height dependent under this heavily shaded environment, which warrants future study to determine the best management practices of these cultivars as well as continued efforts to develop new, shade-tolerant bermudagrass hybrids.

$\mathrm{H}$

ybrid bermudagrass (Cynodon dactylon $\times$ C. transvaalensis) such as 'TifSport' and 'TifGrand' are widely used on golf courses, athletic fields, as well as commercial and residential landscapes because of their tolerance to lower and more frequent mowing, high temperature and drought, and fast recuperative growth (Hanna et al., 2010). However, hybrid bermudagrass tends to have less shade tolerance when compared with other species such as zoysiagrass (Zoysia sp.) and St. Augustinegrass (Stenotaphrum secundatum) (Gardner and Goss, 2013), largely explained by its requirement

Received for publication 19 Feb. 2020. Accepted for publication 17 Mar. 2020.

Published online 22 April 2020.

${ }^{1}$ Department of Crop and Soil Sciences, University of Georgia, Tifton, GA 31793

${ }^{2}$ Department of Agricultural Leadership, Education \& Communication, University of Georgia, Athens, GA 30602

We acknowledge University of Georgia Weather Network for collecting and providing the solar radiation data.

B.S. is the corresponding author. E-mail: tifturf@uga. edu.

This is an open access article distributed under the CC BY-NC-ND license (https://creativecommons. org/licenses/by-nc-nd/4.0/)

https://doi.org/10.21273/HORTTECH04596-20 of greater light intensities to reach a balance of photosynthesis and cellular respiration (Alexander and McCloud, 1962). Shaded conditions, caused either by artificial constructions or trees, have always been a great challenge for turfgrass managers. These challenges are becoming more common as roofed stadiums are being built. Shade results in reduced irradiance and reduced levels of total nonstructural carbohydrates (TNCs) (Schnyder and Nelson, 1989), which makes turfgrass more vulnerable to disease and pests (Giesler et al., 2000). Shaded microenvironments are also typically comprised of greater humidity and limited airflow, which only exacerbates the condition (Giesler et al., 2000). 'TifGrand', as an improved cultivar, has demonstrated better shade tolerance than 'Tifway' and 'TifSport' when grown under $70 \%$ continuous shade (Hanna et al., 2010).

Shoot elongation under shade is a typical response of turfgrass as a result of increased levels of gibberellic acid (Tan and Qian, 2003). This shade avoidance mechanism increases leaf area and light capture, but the drawback is that the photosynthates have been removed when the turfgrass is mowed regularly, leading to weakening physiological status. TE is a plant growth regulator that is formulated to reduce plant vigor by decreasing the biosynthesis of gibberellic acid (King et al., 1997). It is often applied to turfgrass for several beneficial purposes, but in recent years it has been used to reduce shoot elongation on turfgrasses growing under shaded conditions (Fagerness et al., 2002; Wherley and Sinclair, 2009). Several studies have shown increased zoysiagrass performance under shade by inhibiting shoot elongation through TE application (Ervin et al., 2002; Qian and Engelke, 1999; Qian et al., 1998; Riffell et al., 1995). Qian and Engelke (1999) reported an increase of canopy photosynthesis, TNC, tiller density, root weight, and TQ as a result of TE application in 'Diamond' zoysiagrass grown in a shaded environment. In bermudagrass, Bunnell et al. (2005b) reported that 'TifEagle' bermudagrass maintained acceptable TQ under $4 \mathrm{~h}$ sunlight and TE application when mowed at $4.7 \mathrm{~mm}$. Applying TE resulted in a linear TQ increase for 'Champion' bermudagrass grown under $55 \%$ shade (Baldwin et al., 2009). The TE application was also reported to improve ball lie in 'TifSport' when maintained at a 1.5 -inch height (Kowalewski et al., 2012), although the effect was not significant throughout the entire year.

Increasing mowing heights within the recommended range of each turfgrass species can increase turf performance

\begin{tabular}{llll}
\hline $\begin{array}{l}\text { Units } \\
\text { To convert U.S. to SI, } \\
\text { multiply by }\end{array}$ & U.S, unit & SI unit & $\begin{array}{l}\text { To convert SI to } \\
\text { U.S., multiply by }\end{array}$ \\
\hline 0.3048 & $\mathrm{ft}$ & $\mathrm{m}$ & 3.2808 \\
0.0929 & $\mathrm{ft}^{2}$ & $\mathrm{~m}^{2}$ & 10.7639 \\
3.7854 & gal & $\mathrm{L}$ & 0.2642 \\
2.54 & inch $(\mathrm{es})$ & $\mathrm{cm}$ & 0.3937 \\
25.4 & inch $(\mathrm{es})$ & $\mathrm{mm}$ & 0.0394 \\
48.8243 & $\mathrm{lb} / 1000 \mathrm{ft}^{2}$ & $\mathrm{~kg} \cdot \mathrm{ha}^{-1}$ & 0.0205 \\
0.0701 & oz/acre & $\mathrm{kg} \cdot \mathrm{ha}^{-1}$ & 14.2749
\end{tabular}


under shaded conditions (Dudeck and Peacock, 1992). Cutting the grass at a lower mowing height not only removes the most photosynthetic actively tissues, but also alters the leaf orientation, leading to a modification of light compensation point (Beard, 1973; Gardner and Goss, 2013). 'TifEagle' hybrid bermudagrass had better TQ when

Table 1. Daily light integral of a hybrid bermudagrass field study site under $77 \%$ shade in 2010 and 2011.

\begin{tabular}{|c|c|c|}
\hline \multirow[b]{2}{*}{ Month } & 2010 & 2011 \\
\hline & \multicolumn{2}{|c|}{ - $\left(\mathrm{mol} \cdot \mathrm{m}^{-2} \cdot \mathrm{d}^{-1}\right)$} \\
\hline January & $5.14^{\mathrm{z}}$ & 4.68 \\
\hline February & 6.35 & 6.20 \\
\hline March & 7.73 & 7.91 \\
\hline April & 10.77 & 11.37 \\
\hline May & 10.72 & 12.63 \\
\hline June & 11.26 & 11.89 \\
\hline July & 11.02 & 10.51 \\
\hline August & 9.06 & 11.04 \\
\hline September & 8.99 & 8.15 \\
\hline October & 8.39 & 7.39 \\
\hline November & 5.89 & 6.07 \\
\hline December & 4.88 & 4.80 \\
\hline
\end{tabular}

${ }^{\mathrm{z}}$ Data were adapted from University of Georgia Weather Network (University of Georgia, 2019).

maintained at $4.7 \mathrm{~mm}$ than at $3.2 \mathrm{~mm}$ under $4 \mathrm{~h}$ daily sunlight (Bunnell et al., 2005b). Turfgrass quality of bermudagrass was greater at $25 \mathrm{~mm}$ than at $16 \mathrm{~mm}$ under $71 \%$ shade, but there was no difference in TQ under $0 \%$ or $41 \%$ shade (Bunnell et al., 2005a). However, maintaining turfgrass at a higher height of cut has adverse effects on turf performance resulting from greater respiration rate, increased shading within the turf system, and less traffic tolerance (Gardner and Goss, 2013). Zhang et al. (2017) determined the minimum daily light integral for bermudagrass was $\approx 20$ $\mathrm{mol} \cdot \mathrm{m}^{-2} \cdot \mathrm{d}^{-1}$ in summer months. Specifically, they suggested that 'TifGrand' required slightly less light than 'Tifway' bermudagrass to maintain acceptable performance.

To ensure the successful longterm performance of individual hybrid bermudagrass under shaded
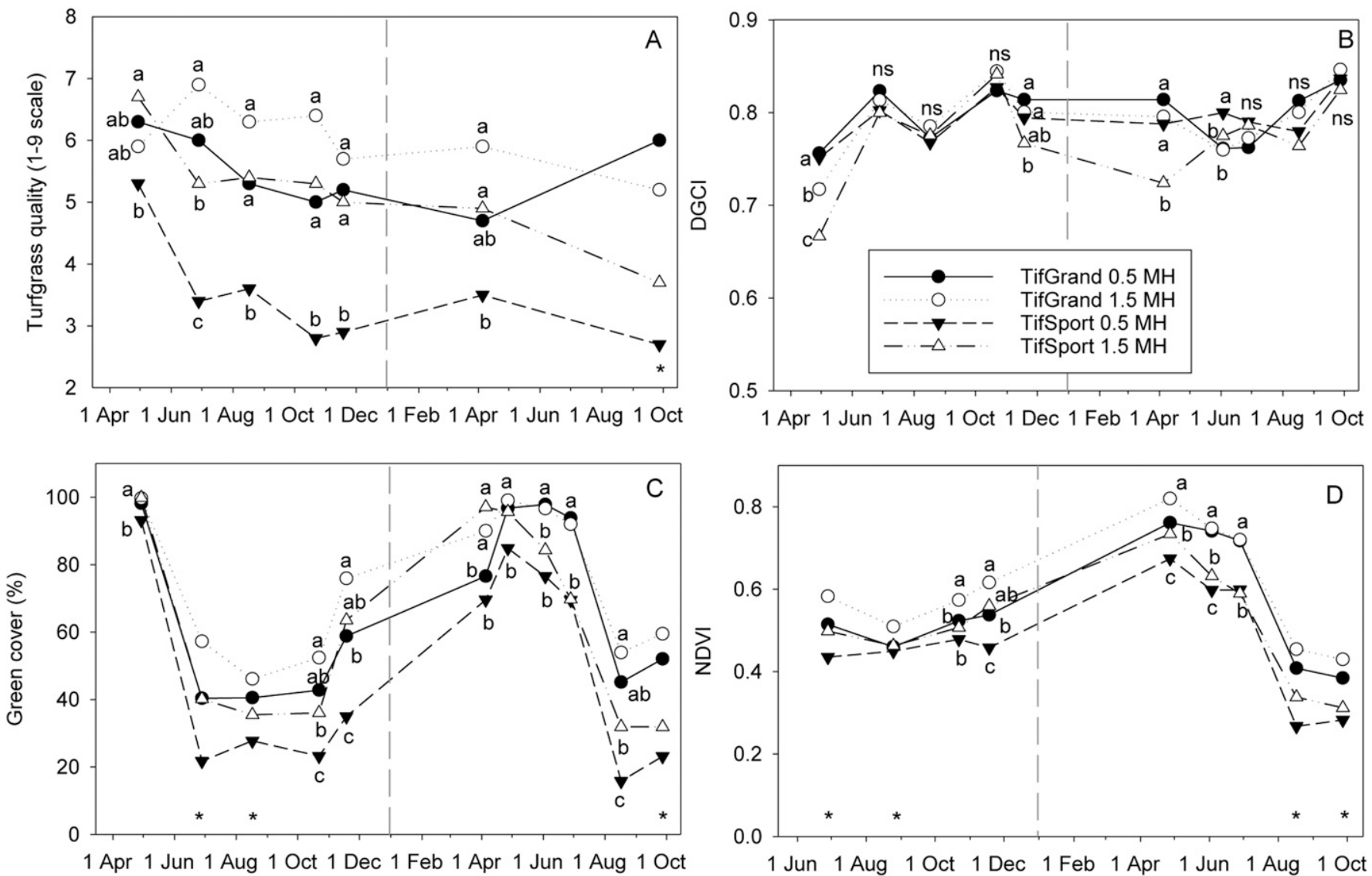

Fig. 1. Interactive effect of cultivar and mowing height on (A) turfgrass quality, (B) dark-green color index (DGCI), (C) green cover, and (D) normalized difference vegetation index (NDVI) in a hybrid bermudagrass field study under $77 \%$ shade in 2010 and 2011 . The gray vertical dash line separates 2010 and 2011 . Data labeled with the same lowercase letter are not significantly different within each date using Tukey's honestly significant difference test $(P \leq 0.05)$. Date labeled with * indicate a three-way interaction (cultivar, mowing height, and trinexapac-ethyl application). Mowing heights (MHs) were 0.5 and 1.5 inch (1.27 and $3.81 \mathrm{~cm}$ ). Minimal acceptable turfgrass quality is 6 . 
conditions, field studies are needed to determine best management practices. Therefore, the objective of this research was to evaluate whether mowing height and TE growth regulator application could improve the turfgrass performance of 'TifGrand' and 'TifSport' under shaded conditions that have been reported too heavy for healthy bermudagrass growth in the southeastern United States.

\section{Materials and methods}

LOCATION, PLANT MATERIALS, AND EXPERIMENT CONDITIONS. Turfgrass research plots $(12 \times 12 \mathrm{ft})$ were established vegetatively from 1 -inchdiameter plugs planted on 1 -foot centers in Oct. 2008 on a loamy sand (Tifton-Urban land complex, $\mathrm{pH}$ 5.3) at the University of Georgia Coastal Plain Experiment Station in Tifton (lat. $31^{\circ} 27^{\prime} 48^{\prime \prime} \mathrm{N}$, long. $\left.83^{\circ} 30^{\prime} 36^{\prime \prime} \mathrm{W}\right)$. Plots were not covered by the shade structure during establishment in 2008 and 2009. Plots was fertilized monthly with 16N-1.7P-6.6K (Super Rainbow Plant Food; Agrium U.S., Denver, $\mathrm{CO})$ at a rate of 0.5 to $1 \mathrm{lb} / 1000 \mathrm{ft}^{2}$ nitrogen $(\mathrm{N})$ from April to October, totaling $5 \mathrm{lb} / 1000 \mathrm{ft}^{2} \mathrm{~N}$ annually. Weekly irrigation (1 inch/week) was applied during the growing season when rainfall was not sufficient during 2008 and 2009.

Mean photosynthetically active radiation at ground level under the Fiberglas-roofed shade structure was reduced $77 \%$ relative to conditions under full sunlight as measured with a quantum meter (Spectrum Technologies, Aurora, IL). This shade level was chosen because 'TifGrand' was able to maintain high TQ under $70 \%$ continuous shade (Hanna et al., 2010), and shade level in the current study was increased based on $70 \%$ shade. The roof of the shade structure was $6 \mathrm{ft}$ above the plots and extended $9 \mathrm{ft}$ beyond the perimeter of the experimental plots. Beginning in Feb. 2010, continuous shade was imposed on the plots until the completion of the experiment in 2011 . Daily light integral under the shade structure for the duration of the study was calculated based on the solar radiation data provided by University of Georgia Weather Network [Table 1 (University of Georgia, 2019)]. Plots received weekly irrigation $(0.5$ inch/week) during the growing seasons of 2010 and 2011 because the roof excluded rainfall.

EXPERIMENTAL DESIGN, TREATMENT AND DATA COLLECTION. The study was arranged as a split-split plot design with five replications, where cultivar was the main plot and mowing height ( 0.5 and 1.5 inch) was the subplot. Plant growth regulator treatment including control and TE application at $2 \mathrm{oz} /$ acre (Primo MAXX; Syngenta, Greensboro, NC) was the sub-subplot. During the study, the plots were mowed once
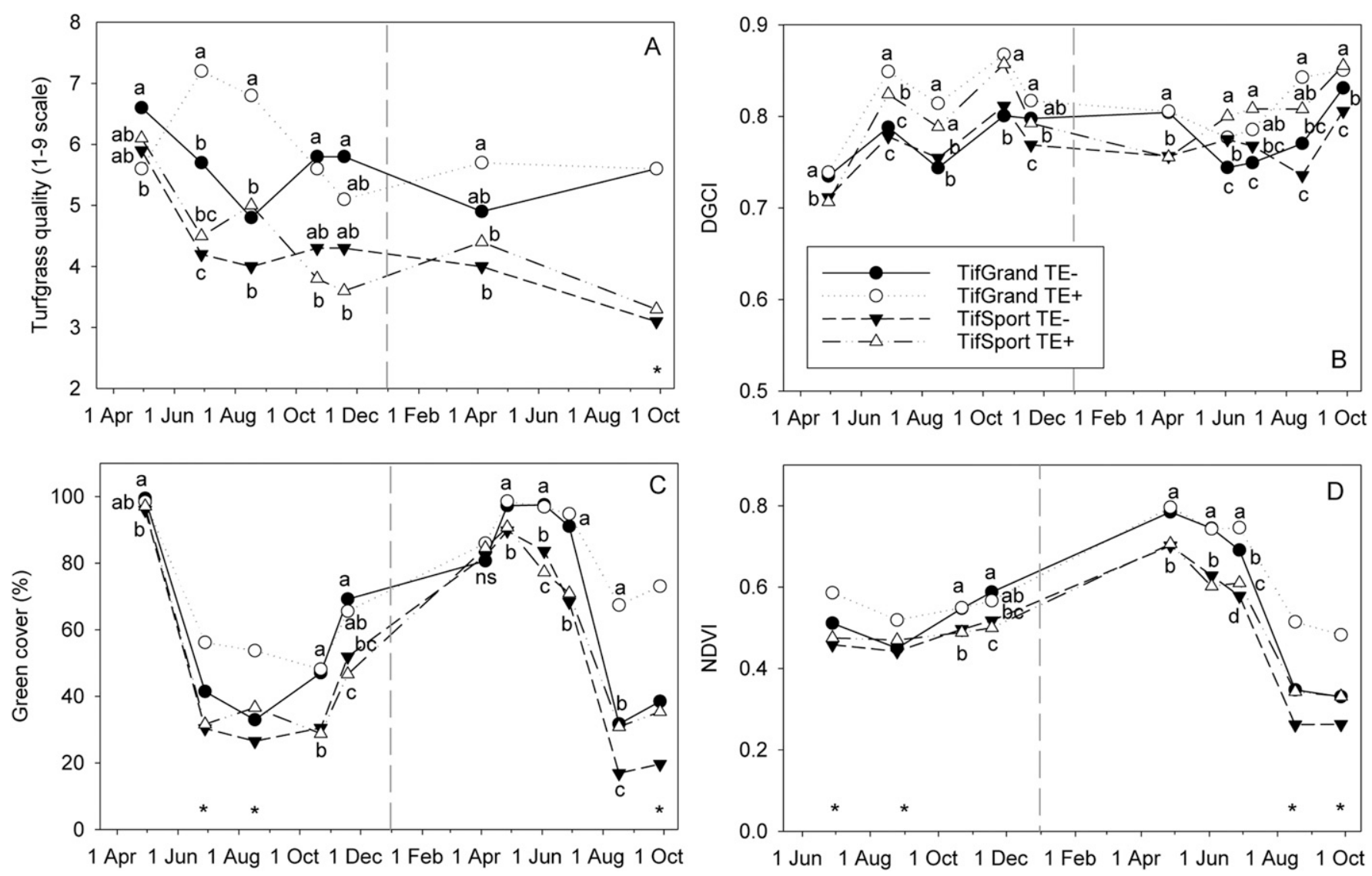

Fig. 2. Interactive effect of cultivar and trinexapac-ethyl (TE) application on (A) turfgrass quality, (B) dark-green color index (DGCI), (C) green cover, and (D) normalized difference vegetation index (NDVI) in a hybrid bermudagrass field study under $77 \%$ shade in 2010 and 2011 . The gray vertical dash line separates 2010 and 2011 . Data labeled with the same lowercase letter are not significantly different within each date using Tukey's honestly significant difference test $(P \leq 0.05)$. Date labeled with * indicate a three way interaction (cultivar, mowing height, and TE application). Minimal acceptable turfgrass quality is 6. 
per week in the spring and fall seasons, and twice per week in summer. The 0.5 -inch mowing height was obtained with a reel mower (3100D Reelmaster Sidewinder; TORO, Bloomington, $\mathrm{MN}$ ) and the 1.5-inch height was obtained with a rotary mower (Grasshopper, Moundridge, KS) equipped with a bagging system. Clippings were removed with both types of mowers. TE was applied twice per month from Mar. to Oct. during 2010 and 2011 with a 15-gal pull-behind sprayer (FIMCO Industries, North Sioux City, SD).

Turf color indicated by DGCI and green cover were evaluated in 29 Apr., 28 June, 17 Aug., 22 Oct., and 18 Nov. 2010; and 5 Apr., 3 June, 28 June, 17 Aug., and 27 Sept. 2011. Digital image analysis was used to measure DGCI and green cover (Richardson et al., 2001). A digital camera (Powershot G5; Canon, Tokyo, Japan) was mounted to an enclosed light box $(1.8 \times 1.8 \mathrm{ft})$ with four compact fluorescent lamps. Images were analyzed using SigmaScan Pro (version 5.0; Systat Software, San Jose, CA). TQ was evaluated on the same dates as green cover in 2010 but only on 5 Apr. and 27 Sept. in 2011 using the National Turfgrass Evaluation Program guidelines on a $\mathbf{1}$ - to 9point scale (Morris and Shearman, 2008), where 1 is dead turf and 9 is ideal green, density, and uniformity, with 6 equal to a minimum acceptable level. NDVI was also obtained using a crop canopy sensor (Crop Circle ACS-470; Holland Scientific, Lincoln, NE) on 28 June, 25 Aug., 22 Oct., and 18 Nov. 2010; and 27 Apr., 3 June, 28 June, 17 Aug., and 27 Sept. 2011 . The system was mounted to a mobile cart at $\approx 2 \mathrm{ft}$ aboveground with a target area of $14 \times 2.5$ inches.

DATA ANAlysis. All data were subjected to analysis of variance using the GLIMMIX procedure in SAS (version 9.4; SAS Institute, Cary, NC). Data were analyzed separately by each evaluation date, and significant main effects were separated using Tukey's honestly significant difference test, with a significance level of 0.05 . When there was a three-way interaction on an evaluation date, the interaction is presented separately.

\section{Results}

TURF PERFORMANCE AFFECTED BY CULTIVAR AND MOWING HEIGHT
UNDER SHADE. The effect of mowing height on TQ was cultivar dependent in our shade study. Turfgrass quality of 'TifGrand' was unaffected by mowing height, but 'TifSport' had a rapid decline of TQ at the 0.5 -inch mowing height after 29 Apr. 2010 (Fig. IA). Of 10 sampling dates, 'TifGrand' only had greater DGCI under lower mowing height on 29 Apr. 2010 and 3 June 2011 (Fig. 1B). Similarly, greater DGCI was found only in 'TifSport' at a lower mowing height on 5 Apr. 2011. Rapid decrease of green cover also occurred after 29 Apr. 2010 and 28 June 2011 in each year (Fig. 1C). 'TifGrand' had greater green cover under a higher mowing height in June 2010, Nov. 2010, and Apr. 2011 only. 'TifSport' had greater green cover under a higher mowing height most of the time, except for June 2011. 'TifGrand' had greater NDVI at a higher mowing height only in 2010 (Fig. 1D). 'TifSport' also exhibited increased NDVI at a higher mowing height except in Aug. and Nov. 2010, and June and Sept. 2011. 'TifGrand' generally had greater TQ, green cover, and NDVI than 'TifSport' (Fig. 1A, C, and D), although it only had greater DGCI than 'TifSport' under the higher mowing height (Fig. 1B).

TURF PERFORMANCE AFFECTED BY CULTIVAR AND TE APPLICATION UNDER SHADE. TQ of 'TifGrand' was increased by TE application only in June 2010 and Aug. 2010, and TE application had no effect on TQ of 'TifSport' (Fig. 2A). There was a three-way interaction observed on 27 Sept. 2011 (Fig. 3). 'TifGrand' had greater TQ at the 0.5 -inch mowing height than the 1.5-inch mowing height when TE was applied. No treatment effect was observed on 'TifSport'. The TE application generally increased DGCI in both 'TifGrand' and 'TifSport' except in April of both years (Fig. 2B). The TE application increased green cover of 'TifGrand' at the lower mowing height whereas 'TifSport' was unaffected (Figs. 2C and 4). In 2010, TE application increased NDVI of 'TifGrand' in June and August only at the lower mowing height, but it did not affect NDVI in 'TifSport' (Figs. 2D and 5). In 2011, TE application increased the NDVI of 'TifGrand' at both mowing heights, but only at the higher mowing height of 'TifSport' (Figs. 2D, and 5C and D).

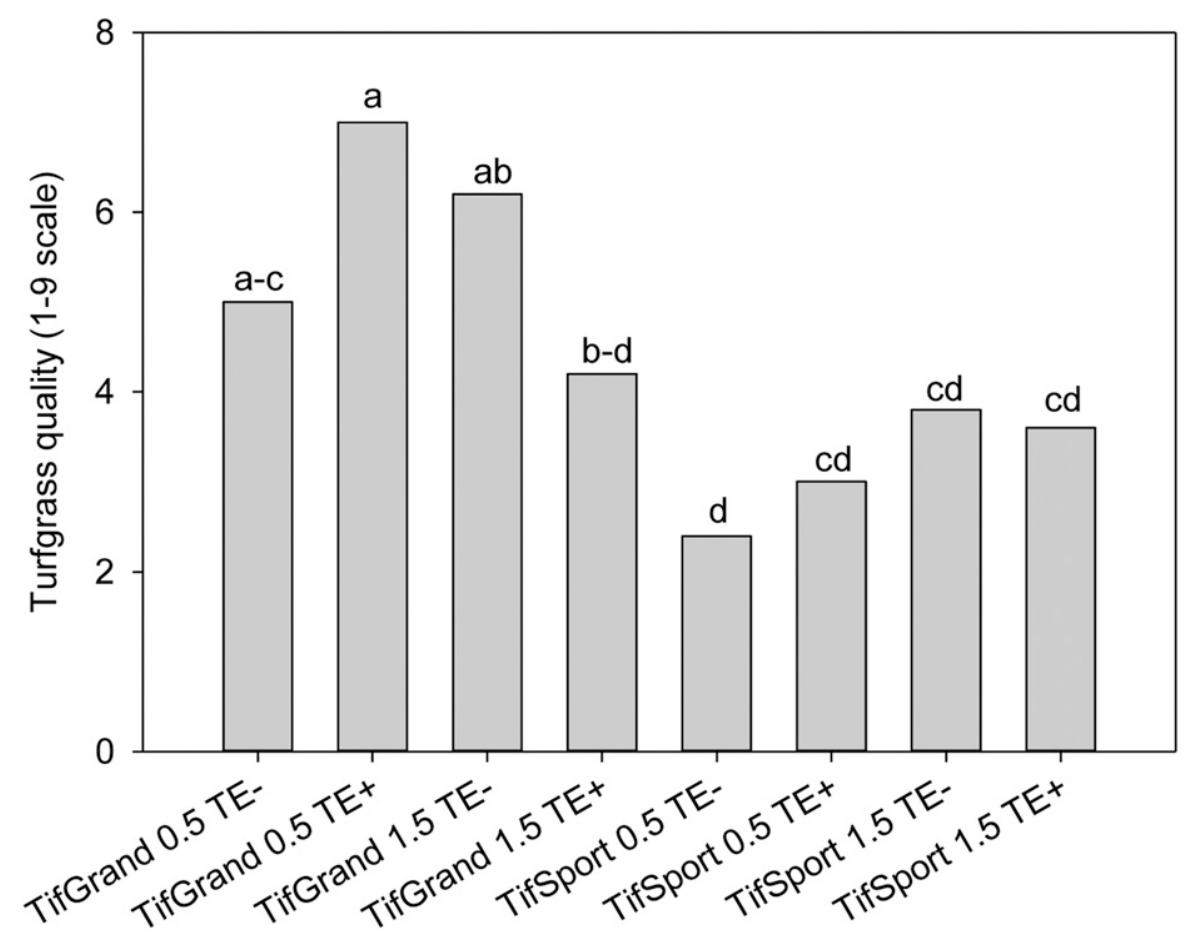

Fig. 3. Interactive effect among cultivar, mowing height, and trinexapac-ethyl (TE) application on turfgrass quality in a hybrid bermudagrass field study under $77 \%$ shade on 27 Sept. 2011. Bars labeled with the same lowercase letter are not significantly different using Tukey's honestly significant difference test $(P \leq 0.05)$. Mowing heights were 0.5 and 1.5 inch $(1.27$ and $3.81 \mathrm{~cm})$. Minimal acceptable turfgrass quality is 6 . 

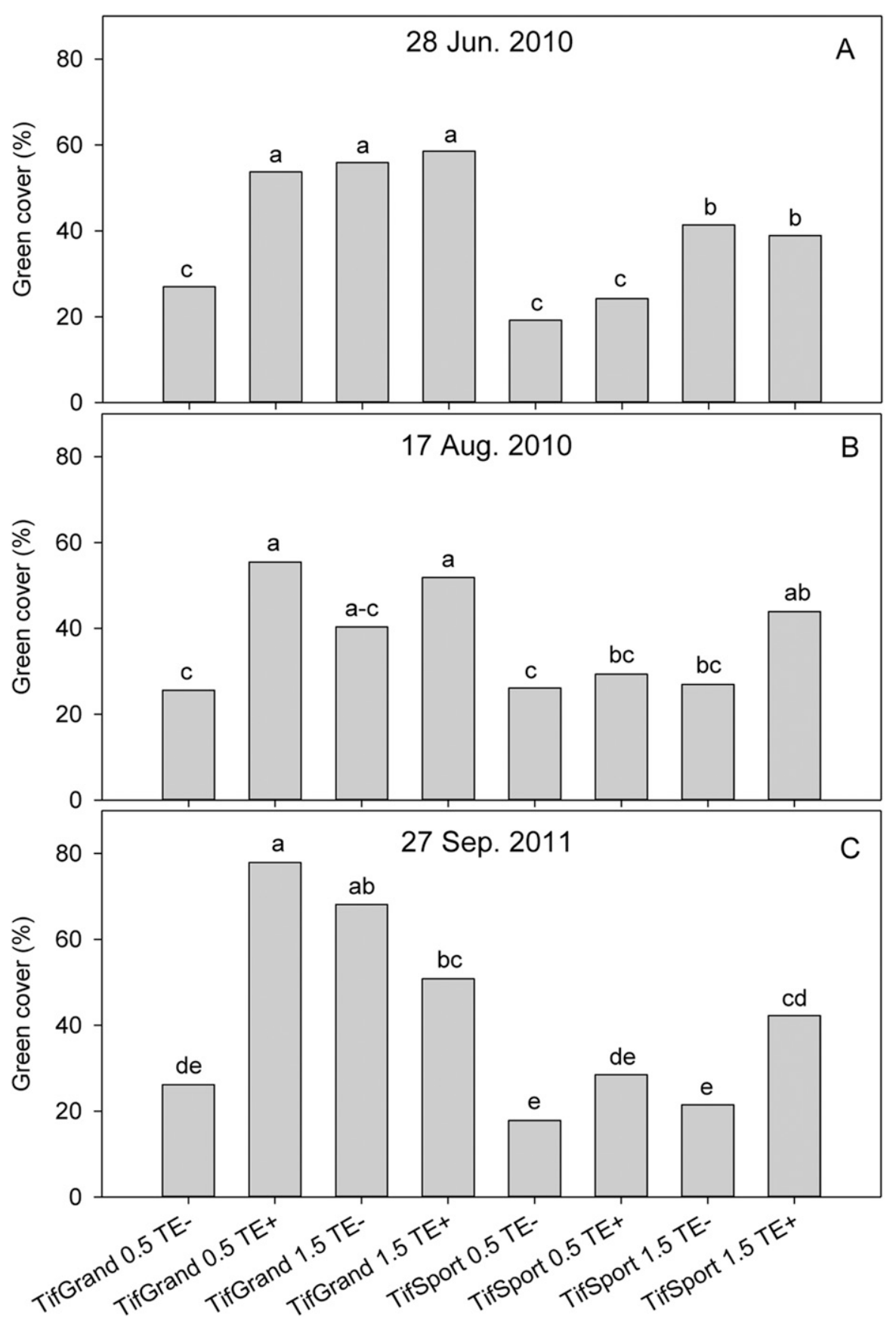

Fig. 4. Interactive effect among cultivar, mowing height, and trinexapac-ethyl (TE) application on green cover in a hybrid bermudagrass field study under $77 \%$ shade on (A) 28 June 2010, (B) 17 Aug. 2010, and (C) 27 Sept. 2011. Bars labeled with the same lowercase letter are not significantly different using Tukey's honestly significant difference test $(P \leq 0.05)$. Mowing heights were 0.5 and 1.5 inch $(1.27$ and $3.81 \mathrm{~cm})$.

\section{Discussion and conclusion}

After the shade treatment was imposed beginning in Feb. 2010, an overall decline in green cover from April to June was observed for both cultivars (Figs. 1 and 2). This was likely a result of the exhaustion of carbohydrate reserves during spring green-up followed by insufficient vegetative growth because of the low light intensity. 'TifGrand' generally had better turf performance under $77 \%$ shade than 'TifSport'. This agreed with the results of Hanna et al. (2010), who found 'TifGrand' had better TQ ratings than 'Tifway' and 'TifSport' under 70\% continuous shade. However, there is little information on the mechanism of better shade tolerance of 'TifGrand'. It could be related to the prostrate growth habit and decreased etiolation of 'TifGrand' (Aldahir, 2015) or other physiological adaptations.

In our study, TE application increased turf color on both cultivars as indicated by DGCI under $77 \%$ shade (Fig. 2). Enhanced turf color in late summer and early fall under TE application was reported on 'TifEagle' hybrid bermudagrass at $3.2 \mathrm{~mm}$ under a full-sun field study ( $\mathrm{McCul}-$ lough et al., 2006). In our research, the effect of TE on TQ, green cover, and NDVI was cultivar dependent. 'TifSport' was not responsive to TE under shade in the study. The reason is unclear, but possibly 'TifSport' had a more severe decline of net photosynthesis than 'TifGrand' under this level of shade, as indicated by $\approx 70 \%$ reduction in green cover from Apr. to June in 2010. Previous studies documented a shifted growth pattern and reallocation of TNC and nutrients to other tissues such as roots or rhizomes in bermudagrass following TE application (McCullough et al., 2006; Waltz et al., 1996).

Turf performance indicated by TQ, green cover, and NDVI of 'TifGrand' was increased by TE application, especially during the summer months of both years when maintained at 0.5 inch, although the beneficial effects of TE application were not found to be significant throughout the entire year. Possibly a mowing frequency of twice per week at 0.5 inch may not be frequent enough for 'TifGrand' during the summer growing season in Tifton, GA. Kowalewski et al. (2014) reported that TQ of 'TifGrand' decreased when mowing frequency was reduced with TE application. Thus, the TE application may be necessary to maintain turfgrass performance of 'TifGrand' during the summer months at lower mowing heights when the mowing frequency is only twice per week.

Dudeck and Peacock (1992) suggested that increasing the mowing height can enhance the turf performance under shade. Previous studies demonstrated the same results in 'TifEagle' (Bunnell et al., 2005b) and 'Tifway' (Bunnell et al., 2005a; Glenn et al., 2014), which agreed with the results in our study. A $29 \%$ increase of light requirement to 


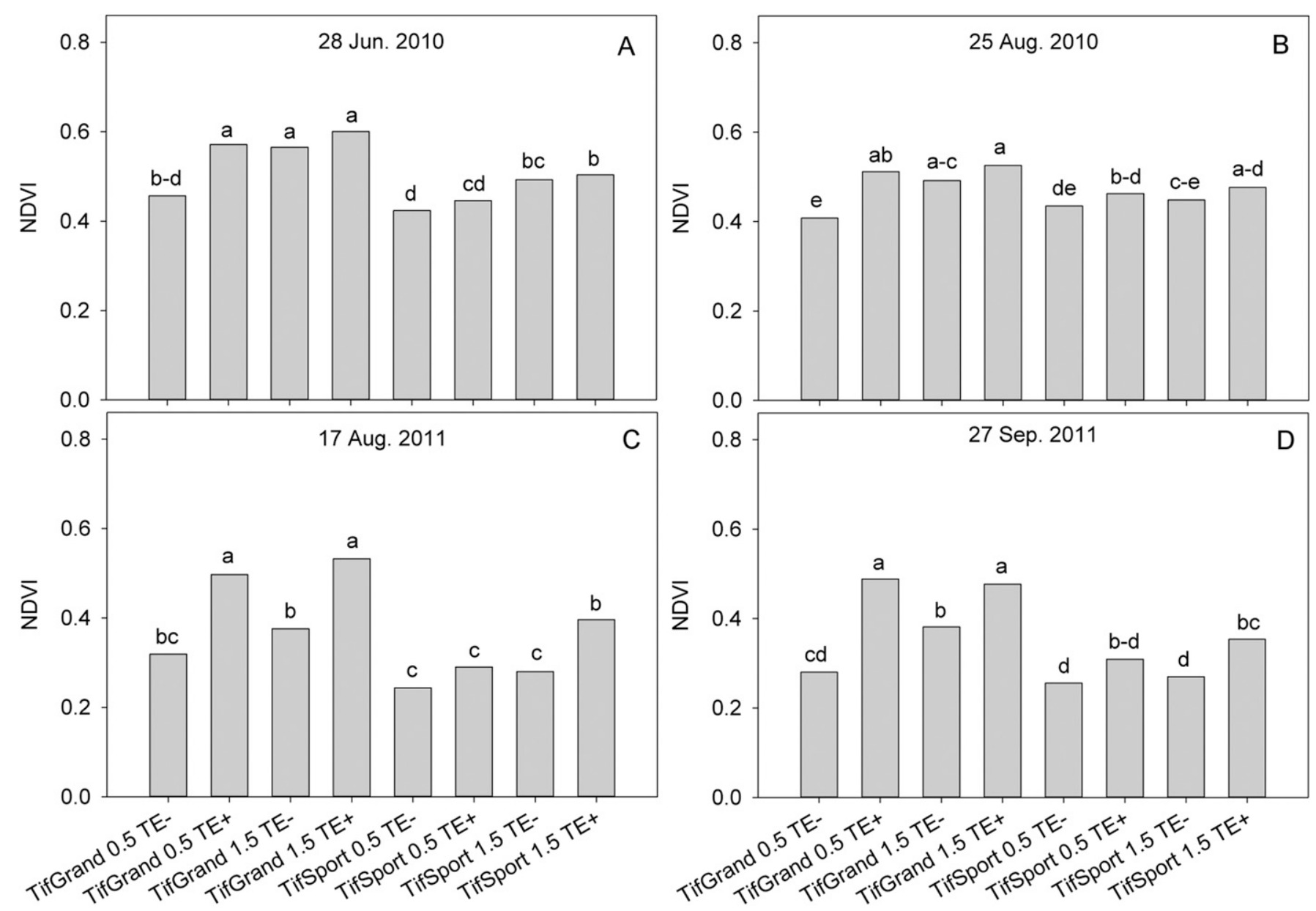

Fig. 5. Interactive effect among cultivar, mowing height, and trinexapac-ethyl (TE) application on normalized difference vegetation index (NDVI) in a hybrid bermudagrass field study under shade on (A) 28 June 2010, (B) 25 Aug. 2010 , (C) 17 Aug. 2011, and (D) 27 Sept. 2011. Bars labeled with the same lowercase letter are not significantly different using Tukey's honestly significant difference test $(P \leq 0.05)$. Mowing heights were 0.5 and 1.5 inch $(1.27$ and $3.81 \mathrm{~cm})$.

maintain TQ for 'Tifway' was reported when the mowing height was reduced from 1.5 to 0.5 inch (Glenn et al., 2014). In our study, 'TifSport' had greater TQ, green cover, and NDVI at the higher mowing height. Although visual TQ did not differ between the two mowing heights for 'TifGrand', greater green cover and NDVI was found at 1.5 inches than 0.5 inch, especially without TE application.

In summary, 'TifSport' and 'TifGrand' were not able to maintain acceptable TQ under $77 \%$ shade throughout the year, although at times 'TifGrand' did maintain minimally acceptable TQ $(\approx 6)$ at the higher mowing height ( 1.5 inches) and demonstrated better shade performance than 'TifSport'. TE application was not able to enhance the turf performance of 'TifSport' under $77 \%$ shade when mowed at 0.5 inch, but it did improve the performance of 'TifGrand' at that height. This level of shade is likely too heavy for the longterm successful management of either 'TifSport' or 'TifGrand' hybrid bermudagrass, which warrants the future research of additional mowing or growth regulator management strategies and the continued breeding and selection of new bermudagrass hybrids specifically for performance in low-light conditions.

\section{Literature cited}

Aldahir, P. 2015. Utilization of 'TifGrand' bermudagrass for sports turf: Wear tolerance, shade response, and quality improvement. PhD Diss., Auburn Univ., Auburn, AL. 17 Mar. 2020. $<$ https://etd.auburn.edu/handle/10415/ $4517>$.

Alexander, C.W. and D.E. McCloud. 1962. $\mathrm{CO}_{2}$ uptake (net photosynthesis) as influenced by light intensity of isolated bermudagrass leaves contrasted to that of swards under various clipping regimes. Crop Sci. 2(2):132-135.

Baldwin, C.M., H. Liu, L.B. McCarty, H. Luo, and J.E. Toler. 2009. Nitrogen and plant growth regulator influence on 'Champion' bermudagrass putting green under reduced sunlight. Agron. J. 101(1): 75-81.

Beard, J. 1973. Turfgrass: Science and culture. Prentice-Hall, Englewood Cliffs, NJ.

Bunnell, B., L. McCarty, and W. Bridges. Jr. 2005a. Evaluation of three bermudagrass cultivars and Meyer japanese zoysiagrass grown in shade. Intl. Turfgrass Soc. Res. J. 10(2):825-833.

Bunnell, B.T., L.B. McCarty, and W.C. Bridges. 2005b. 'TifEagle' bermudagrass response to growth factors and mowing height when grown at various hours of sunlight. Crop Sci. 45(2):575581 . 
Dudeck, A.E. and C.H. Peacock. 1992. Shade and turfgrass culture, p. 269-284. In: D.V. Waddington, R.N. Carrow, and R.C. Shearman (eds.). Turfgrass Agronomy Monograph 32. ASA, CSSA, SSSA, Madison, WI.

Ervin, E.H., C.H. Ok, B.S. Fresenburg, and J.H. Dunn. 2002. Trinexapac-ethyl restricts shoot growth and prolongs stand density of 'Meyer' zoysiagrass fairway under shade. HortScience 37:502-505.

Fagerness, M.J., F.H. Yelverton, D.P. Livingston, and T.W. Rufty. 2002. Temperature and trinexapac-ethyl effects on bermudagrass growth, dormancy, and freezing tolerance. Crop Sci. 42(3):853858 .

Gardner, D.S. and R.M. Goss. 2013. Management of turfgrass in shade, p. 219247. In: J.C. Stier, B.P. Horgan, and S.A. Bonos (eds.). Turfgrass: Biology, use, and management. Agronomy monograph 56. ASA, CSSA, SSSA, Madison, WI.

Giesler, L.J., G.Y. Yuen, and G.L. Horst. 2000. Canopy microenvironments and applied bacteria population dynamics in shaded tall fescue. Crop Sci. 40(5):13251332.

Glenn, B., J. Kruse, and J.B. Unruh. 2014. Effect of mowing height on DLI requirements for warm-season turfgrass. ASA, CSSA, SSSA Annu. Mtg., Long Beach, CA (abstr.).

Hanna, W.W., S.K. Braman, and B.M. Schwartz. 2010. 'ST-5', a shade-tolerant turf bermudagrass. HortScience 45:132134.
King, R.W., C. Blundell, L.T. Evans, L.N. Mander, and J.T. Wood. 1997. Modified gibberellins retard growth of cool-season turfgrasses. Crop Sci. 37(6):1878-1883.

Kowalewski, A.R., B.M. Schwartz, A.L. Grimshaw, J.N. McCrimmon, and J.M. Layton. 2014. Mowing requirement and cost to maintain bermudagrass is influenced by cultivar selection and trinexapacethyl use. Appl. Turfgrass Sci. 11(1), doi: 10.2134/ATS-2014-0019-RS.

Kowalewski, A.R., B.M. Schwartz, M.D. Richardson, D.E. Karcher, J.H. McCalla, A.J. Patton, and W.W. Hanna. 2012. Effects of nitrogen, growth regulators, and mowing height on ball lie in TifSport bermudagrass. Appl. Turfgrass Sci. 9(1), doi: 10.1094/ATS-2012-0625-01-RS.

McCullough, P.E., H. Liu, L.B. McCarty, T. Whitwell, and J.E. Toler. 2006. Bermudagrass putting green growth, color, and nutrient partitioning influenced by nitrogen and trinexapac-ethyl. Crop Sci. 46(4):1515-1525.

Morris, K.N. and R.C. Shearman. 2008. NTEP turfgrass evaluation guidelines. 17 Mar. 2020. <http//www.ntep.org/pdf/ ratings.pdf $>$.

Qian, Y.L. and M.C. Engelke. 1999. Influence of trinexapac-ethyl on Diamond zoysiagrass in a shade environment. Crop Sci. 39(1):202-208.

Qian, Y.L., M.C. Engelke, M.J.V. Foster, and S. Reynolds. 1998. Trinexapac-ethyl restricts shoot growth and improves quality of 'Diamond' zoysiagrass under shade. HortScience 33:1019-1022.
Richardson, M.D., D.E. Karcher, and L.C. Purcell. 2001. Quantifying turfgrass cover using digital image analysis. Crop Sci. 4l(6):1884-1888.

Riffell, S., M. Engelke, and S. Morton. 1995. Performance of three warm-season turfgrasses cultured in shade: Zoysiagrass. Texas Turfgrass Res. 95(11):60-65.

Schnyder, H. and C.J. Nelson. 1989. Growth rates and assimilate partitioning in the elongation zone of tall fescue leaf blades at high and low irradiance. Plant Physiol. 90(3):1201-1206.

Tan, Z.G. and Y.L. Qian. 2003. Light intensity affects gibberellic acid content in kentucky bluegrass. HortScience 38:113116.

University of Georgia. 2019. University of Georgia Weather Network. 17 Mar. 2020. <http://www.georgiaweather. net $/>$.

Waltz, F.C., Jr., T. Whitwell, W.B. Miller, and L.W. Grimes. 1996. The effect of trinexapac-ethyl of total carbohydrates in field grown hybrid bermudagrass. Agron. Abstr. 145.

Wherley, B. and T.R. Sinclair. 2009. Growth and evapotranspiration response of two turfgrass species to nitrogen and trinexapac-ethyl. HortScience 44:20532057.

Zhang, J., B. Glenn, J.B. Unruh, J.K. Kruse, K.E. Kenworthy, J. Erickson, D. Rowland, and L.E. Trenholm. 2017. Comparative performance and daily light integral requirements of warm-season turfgrasses in different seasons. Crop Sci. 57(4):2273-2282. 